\title{
New Spectrophotometric Method for the Assessment of Catalase Enzyme Activity in Biological Tissues
}

\author{
Thulfeqar A. Hamza ${ }^{1}$, Mahmoud Hussein Hadwan ${ }^{2, *}$ \\ 1 pathological analysis Dept., Al-Mustaqbal University College, Hilla city, Babylon
Governorate, lraq \\ ${ }^{2}$ Chemistry Dept., College of Science, University of Babylon, Hilla city, Babylon Governorate, \\ p.o. 51002, Iraq \\ * Corresponding author. \\ Email address: mahmoudhadwan@gmail.com
}

\begin{abstract}
:
Background: Catalase is a vital antioxidant enzyme that dismutates $\mathrm{H}_{2} \mathrm{O}_{2}$ into water and molecular oxygen. Many protocols have been developed to measure catalase enzyme activity. Spectrophotometric methods are the most common assays that used to assess catalase enzyme activity.
\end{abstract}

Methods: Because the rate-limiting step during catalase enzyme activity depends upon the dissociation of hydrogen peroxide, the developed assay measures the reaction between a hydroquinone/anilinium sulfate/ammonium molybdate reagent and Unreacted Hydrogen Peroxide, which results in the production of a purple, disubstituted quinone compound with a maximum absorbance value at $550 \mathrm{~nm}$.

Results: To clarify the precision of the developed method, the coefficients of variation were determined to be $2.6 \%$ and $4.7 \%$ for within run measurements and between run measurements, respectively. This method returned results that correlated well $(\mathrm{r}=$ 0.9982) with the results returned using the peroxovanadate method to assess catalase enzyme activity. Additionally, we examined the use of the newly developed hydroquinone assay to measure catalase enzyme activity in liver and bacterial homogenate samples.

Conclusion: These results demonstrated that this assay can be used for scientific research and routine health applications because it is inexpensive, simple, accurate, and rapid. This method is suitable for use in clinical pathology laboratories because it is simple and produces precise and reproducible results.

Keywords: catalase activity; hydrogen peroxide; hydroquinone; anilinium sulfate; ammonium molybdate. 


\section{Introduction}

Catalase is a vital antioxidant enzyme that dismutates $\mathrm{H}_{2} \mathrm{O}_{2}$ into water and molecular oxygen [1]. Catalase can be found in animal cells, plant cells, and aerobic microorganisms, and within the human body, catalase has been identified in erythrocytes, kidney, and liver, where it is typically considered to be a component in the major defense system against $\mathrm{H}_{2} \mathrm{O}_{2}$ formation [2]. Measuring changes in the endogenous antioxidant activity of catalase enzyme has previously been used to quantify reactive oxygen species [3]. Therefore, the assessment of catalase enzyme activity is essential and vital to the evaluation of oxidative stress in biological tissues.

Many protocols have been developed to measure catalase enzyme activity. The most common assay used to assess catalase enzyme activity is the ultraviolet (UV) spectrophotometric protocol, which measures the catalase enzyme-mediated dismutation of hydrogen peroxide into molecular oxygen and water as a change in absorbance at $240 \mathrm{~nm}$ [4]. However, the application of the UV spectrophotometric method is limited for the following reasons [5]. First, catalase enzyme activity can be inhibited by alterations in the structures of catalase active sites that occur in the presence of high concentrations of $\mathrm{H}_{2} \mathrm{O}_{2}$. Second, DNA and proteins absorb UV light, making the UV spectrophotometric method unsuitable for the assessment catalase enzyme activity in biological tissues [6].

Spectrophotometric methods have widely been used to estimate catalase enzyme activity, using diverse reagents to form colored complexes that absorb light within the visible spectrum, such as the ferrous oxidation in xylenol orange (FOX) assay [7] that absorbs at $560 \mathrm{~nm}$, the carbonate cobaltate(III) complex that absorbs light at $440 \mathrm{~nm}$ [8], the indamine dye with a water-soluble ironporphyrin [9] that absorb at 590 $\mathrm{nm}$, and the peroxovanadate complex $\left(\mathrm{NH}_{4}\left[\mathrm{VO}\left(\mathrm{O}_{2}\right) \mathrm{SO}_{4}\right)\right.$ that absorbs light at $452 \mathrm{~nm}$ [10]. Shivakumar et al., [11] utilized an isonicotinic acid hydrazidepyrocatechol system to examine the dissociation of hydrogen peroxide and assess catalase activity.

Optical sensors have also been used to assess catalase activity. For the continuous determination of hydrogen peroxide concentrations, Posch and Wolfbeis [12] described three types of sensors that measure the oxygen levels formed in response to the dissociation of hydrogen peroxide by a specific catalyst. The fluorescence quenching of a silica gel-adsorbed dye entrapped in silicone rubber was utilized to 
quantify changes in oxygen levels and applied to the assessment of catalase enzyme activity. Cohen and Weber [13] described a device for the detection and generation of hydrogen peroxide, in situ, using gold-coated optical fiber. This device photochemically produces and electrochemically senses $\mathrm{H}_{2} \mathrm{O}_{2}$ in aqueous buffered samples and was utilized to assess catalase enzyme activity. Finally, Bekdeşer et al., [14] developed a low-cost and rapid optical sensor based cupric reducing antioxidant capacity (CUPRAC) assay to assess catalase enzyme activity in liver and kidney tissue homogenates.

Special methods have been developed based upon the estimation of liberated oxygen concentrations, in response to the dissociation of $\mathrm{H}_{2} \mathrm{O}_{2}$. Oxygen generation can be quantified using a low-flow gas meter [15] or oxygen electrodes [16].

Another method utilizes different probes in the presence of peroxidase or peroxidase mimics $[17,18,19]$ to detect the residual $\mathrm{H}_{2} \mathrm{O}_{2}$ concentration. However, peroxidase is expensive and very unstable in solution [20].

In this manuscript, we report a simple spectrophotometric method for rapidly measuring catalase activity, based on the measurement of $\mathrm{H}_{2} \mathrm{O}_{2}$. This method utilizes a reaction between a hydroquinone/anilinium sulfate/ammonium molybdate reagent and unreacted hydrogen peroxide, which yields a purple, disubstituted quinone compound with a maximum absorbance at $550 \mathrm{~nm}$. This new method is inexpensive, rapid, simple, and accurate and can be applied to systematic research analyses and routine clinical measurements.

\section{Materials and Methods}

\subsection{Chemicals}

All chemical substances were attained from standard commercial suppliers.

\subsection{Principle}

The current method utilized the reaction between a hydroquinone/anilinium sulfate /ammonium molybdate reagent and unreacted hydrogen peroxide, which forms a purple, disubstituted quinone compound with a maximum absorbance at $550 \mathrm{~nm}$. The reaction between hydroquinone and aniline in the presence of $\mathrm{H}_{2} \mathrm{O}_{2}$ is shown in Scheme $1[21]$. 


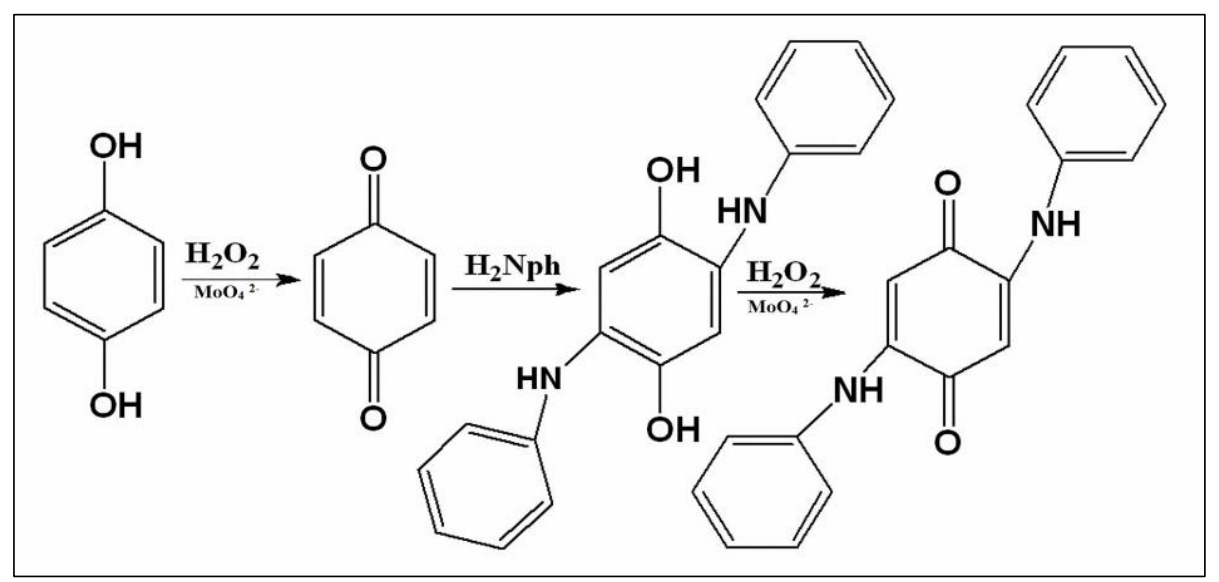

Scheme 1. Proposed reaction for the formation of purple -colored product of the disubstituted quinone compound.

The system, $\mathrm{H}_{2} \mathrm{O}_{2} / \mathrm{MoO}_{4}{ }^{2-}$, could act as a peroxidizing agent via the generation of singlet oxygen $\left({ }^{1} \mathrm{O}_{2}\right)$ [22], as shown in equations 1 and 2 [23]. Subsequently, ${ }^{1} \mathrm{O}_{2}$ molecules react with reduced hydroquinone to form the oxidized form.

$\mathrm{MoO}_{4}{ }^{2-}+\mathrm{nH}_{2} \mathrm{O}_{2} \leftrightarrows \mathrm{MoO}_{4-\mathrm{n}}\left(\mathrm{O}_{2}\right)_{\mathrm{n}}^{2-}+\mathrm{nH}_{2} \mathrm{O}$

$\mathrm{MoO}_{4-\mathrm{n}}\left(\mathrm{O}_{2}\right)_{\mathrm{n}}{ }^{2-} \stackrel{\mathrm{n}=2-4}{\longrightarrow}{ }^{1} \mathrm{O}_{2}+\mathrm{MoO}_{6-\mathrm{n}}\left(\mathrm{O}_{2}\right)_{\mathrm{n}-2}{ }^{2-}$

\subsection{Reagents}

(1) Hydroquinone solution $(0.25 \mathrm{~mol} / \mathrm{L})$ was composed of $2.75 \mathrm{~g}$ hydroquinone in 100 $\mathrm{ml}$ of distilled water (DW).

(2) Anilinium sulfate solution $(0.125 \mathrm{~mol} / \mathrm{L})$ was composed of $3.554 \mathrm{~g}$ anilinium sulfate dissolved in $100 \mathrm{ml} \mathrm{DW}$.

(3) Ammonium molybdate solution $(0.05 \%)$ was composed of $0.5 \mathrm{~g}$ ammonium molybdate dissolved in $100 \mathrm{ml} \mathrm{DW}$.

(4) Working reagent was prepared freshly by mixing anilinium sulfate (200 ml), hydroquinone $(300 \mathrm{ml})$, and ammonium molybdate $(100 \mathrm{ml})$. The sequence of addition for the component solutions was very important to the achievement of accurate results.

(5) Phosphate buffer (pH 7.4, $50 \mathrm{mM}$ ): solution (a) was composed of $6.81 \mathrm{~g} \mathrm{KH}_{2} \mathrm{PO}_{4}$ dissolved in 11 of DW, and solution (b) was composed $8.90 \mathrm{~g} \mathrm{Na}_{2} \mathrm{HPO}_{4} .2 \mathrm{H}_{2} \mathrm{O}$ dissolved in 11 of DW; freshly prepared phosphate buffer was prepared by mixing (a):(b) at a $1: 1.5$ ratio. 
(6) Hydrogen peroxide solution (10 mM) was freshly prepared by mixing $114 \mu \mathrm{L} \mathrm{H}_{2} \mathrm{O}_{2}$ (30\%) with $100 \mathrm{ml}$ phosphate buffer.

\subsection{Erythrocyte samples}

Three milliliters of whole blood were used to prepare erythrocyte lysates. The blood was drawn from a researcher in the Department of Chemistry at the University of Babylon (Iraq). The heparinized whole blood was centrifuged at $400 \times \mathrm{g}$ for $10 \mathrm{~min}$, and then the buffy coat and plasma were removed and disposed. Subsequently, aliquots of the resulting red blood cells $(500 \mu \mathrm{l})$ were washed three times with $5 \mathrm{ml} \mathrm{NaCl}$ solution $(0.9 \%)$. The samples were centrifuged after each wash at $500 \times \mathrm{g}$ for $10 \mathrm{~min}$. The test tubes were vortexed for five seconds after the addition of $2 \mathrm{ml}$ ice-cold DW. Then, the test tubes were incubated at $4{ }^{\circ} \mathrm{C}$, for $15 \mathrm{~min}$ in the dark. Stock hemolysates were resuspended in phosphate buffer solution $(0.05 \mathrm{M})$, at a dilution factor of 500 . The resulting erythrocyte lysates were utilized as a suitable source of catalase enzyme activity.

\subsection{Tissue preparations}

The central animal house of the College of Science at the University of Babylon, Iraq provided male albino mice and rats. Broiler chickens were obtained from the central market (Hilla City, Iraq). Liver tissues were surgically excised immediately after the animals were sacrificed. Livers were washed with $0.9 \% \mathrm{NaCl}$ solution (w/v) to eliminate blood and contaminates, and then the liver tissues were homogenized in $1.15 \%(\mathrm{w} / \mathrm{v})$ cold $\mathrm{KCl}$. After filtration, the resulting sample was diluted with $0.05 \mathrm{M}$ phosphate buffer solution, at a ratio of 1:500, and utilized as a suitable source of catalase enzyme activity.

\subsection{Instrument}

A spectrophotometer (Shimadzu 1800) was utilized in this study.

\subsection{Procedure}

The procedure utilized to assess catalase activity is shown in Table $\mathbf{1}$.

Table 1. Details of the procedure utilized to assess catalase activity.

\begin{tabular}{|l|l|l|l|}
\hline Reagents & Test & Standard & Blank \\
\hline Sample & $1000 \mu \mathrm{l}$ & ----- & ----- \\
\hline Distilled water & ----- & $1000 \mu \mathrm{l}$ & $3000 \mu \mathrm{l}$ \\
\hline Hydrogen peroxide & $2000 \mu \mathrm{l}$ & $2000 \mu \mathrm{l}$ & ----- \\
\hline $\begin{array}{l}\text { Test tubes were vortexed and incubated at } 37^{\circ} \mathrm{C} \text { for } 2 \mathrm{~min} \text { and the following reagent } \\
\text { was added thereafter: }\end{array}$ & $6 \mathrm{ml}$ & $6 \mathrm{ml}$ \\
\hline Working reagent & 6
\end{tabular}


Test tubes were vortexed and incubated at room temperature for $10 \mathrm{~min}$, and absorbance was read at $550 \mathrm{~nm}$.

\subsection{Calculation}

Catalase enzyme activity was determined according to the rate constant of a first-order reaction equation $(\mathrm{k})$ :

$$
\text { Catalase Activity of test } \mathrm{kU}=\frac{2.303}{\mathrm{t}} * \log \frac{\mathrm{S}^{\mathrm{o}}}{\mathrm{S}}
$$

where $t$ is time, $S^{\circ}$ is the absorbance of the standard test tube, and $S$ is the absorbance of the sample test tube.

\section{Results and Discussion}

The current method utilized the reaction between a hydroquinone/anilinium sulfate/ammonium molybdate reagent and unreacted hydrogen peroxide, resulting in the formation of a purple, disubstituted quinone compound with a maximum absorbance at $550 \mathrm{~nm}[21]$.

The method takes place in a neutral $\mathrm{pH}$, and this is an additional positive feature. In the present method, the hydroquinone/anilinium sulfate/ammonium molybdate reagent acts as a catalase enzymatic reaction stop bath. Ammonium molybdate reagent was used to halt the catalase reaction via consume all the hydrogen peroxide molecules. Ammonium molybdate reacts with $\mathrm{H}_{2} \mathrm{O}_{2}$ molecule that is not dissociated by the catalase enzyme to form singlet oxygen $\left({ }^{1} \mathrm{O}_{2}\right)$. Subsequently, ${ }^{1} \mathrm{O}_{2}$ molecules react with reduced hydroquinone to form the oxidized form in the presence of aniline and molybdate to form a purple, disubstituted quinone compound (Fig. 1a).

A reduction in the intensity of the purple disubstituted quinone compound is associated with increased catalase activity (Fig. 1b). The spectrum of the resulting disubstituted quinone compound was scanned from $330 \mathrm{~nm}$ to $700 \mathrm{~nm}$, and the maximum absorbance was observed at $550 \mathrm{~nm}$ (Fig. 1c); therefore, this peak was used to measure catalase activity. 


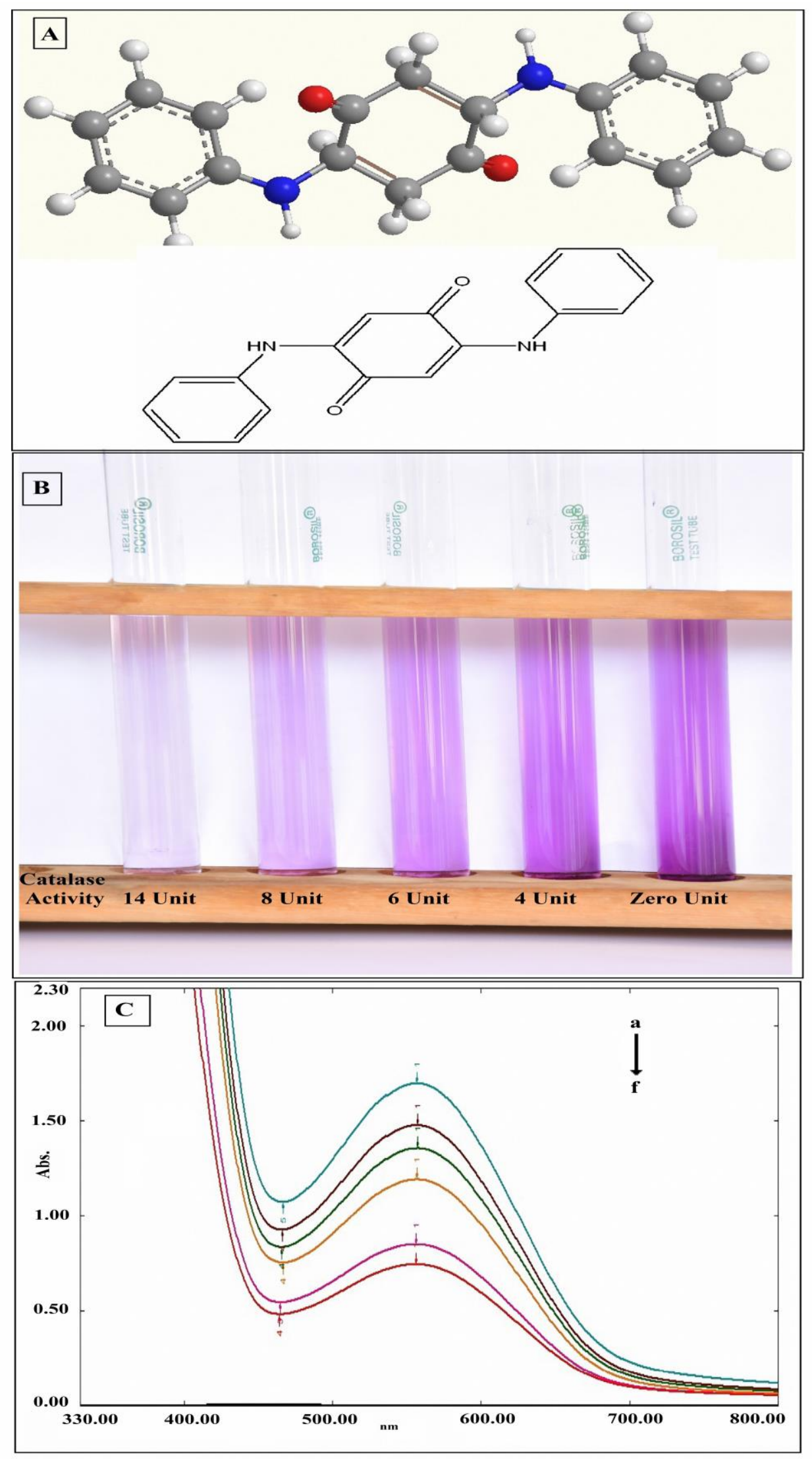

Fig. 1. Catalase enzyme activity correlated with the spectrophotometric properties of the disubstituted quinone. A The disubstituted quinone compound. B Catalase enzyme activity was linked to reductions in color intensity of the resulting disubstituted quinone compound. $\mathbf{C}$ Absorption spectra achieved for the resulting disubstituted quinone compound: (a) $16 \mathrm{mM} \mathrm{H}_{2} \mathrm{O}_{2}$; (b) $15 \mathrm{mM} \mathrm{H}_{2} \mathrm{O}_{2}$; (c) $14 \mathrm{mM} \mathrm{H}_{2} \mathrm{O}_{2}$; (d) $12 \mathrm{mM} \mathrm{H}_{2} \mathrm{O}_{2}$; (e) $8 \mathrm{mM} \mathrm{H}_{2} \mathrm{O}_{2}$; and (f) $6 \mathrm{mM}$ $\mathrm{H}_{2} \mathrm{O}_{2}$. 
The optimal incubation time for the measurement of catalase enzyme activity was assessed by determining the activity of 5 units of catalase activity (HiMedia company; the code product: TC037, India) using the current method. In the current study, catalase enzyme solution was prepared in cold phosphate buffer $(\mathrm{pH} 7 ; 50 \mathrm{mM})$. The resulting activity was standardized using the peroxovanadate protocol, as described by Hadwan and Ali [10]. Table 2 shows that the optimal incubation time was determined to be 120 sec.

Table (2): Correlation between incubation time and catalase activity.

\begin{tabular}{|l|c|c|c|c|c|c|}
\hline $\begin{array}{l}\text { Prepared catalase } \\
\text { enzyme activity }\end{array}$ & 5 & 5 & 5 & 5 & 5 & 5 \\
\hline $\begin{array}{l}\text { Incubation time } \\
\text { (sec) }\end{array}$ & 60 & $120^{\mathrm{b}}$ & 180 & 240 & 300 & 360 \\
\hline $\begin{array}{l}\text { Obtained catalase } \\
\text { enzyme activity }\end{array}$ & $3.0 \pm 0.5$ & $5.1 \pm 0.1$ & $5.0 \pm 0.35$ & $4.8 \pm 0.3$ & $4.8 \pm 0.5$ & $4.8 \pm 0.3$ \\
\hline $\begin{array}{l}\text { a mean of triplicate determinations. } \\
\text { b optimal incubation time. }\end{array}$
\end{tabular}

The protocol described by Hadwan and Abid [24] was used to determine the potential interference of the chemicals used during the current method for the assessment of catalase activity. In brief, $9 \mathrm{ml}$ solutions of potentially interfering chemicals (Table 3), were prepared in phosphate buffer solution $(\mathrm{pH} \mathrm{7.4;50} \mathrm{mM})$ and mixed with $1 \mathrm{ml}$ catalase enzyme solutions with previously determined activity levels $(30 \mathrm{U} / \mathrm{mL})$. The peroxovanadate method was used to calibrate the observed catalase activity. The final enzyme activity was determined to be $3 \mathrm{U} \cdot \mathrm{mL}^{-1}$. Table 3 lists the effects of all examined potentially interfering chemicals on the assessment of catalase activity.

Table 3. The probable interference of selected chemicals on the assessment of catalase enzyme activity using the disubstituted quinone method.

\begin{tabular}{|c|c|c|c|c|}
\hline Chemicals & $\begin{array}{c}\text { Concentration of } \\
\text { chemical }\end{array}$ & $\begin{array}{c}\text { Added } \\
\text { catalase/ } \\
\text { Unit }\end{array}$ & $\begin{array}{c}\text { Found catalase/ } \\
\text { Unit }\end{array}$ & $\begin{array}{c}\text { Relative error } \\
(\%)\end{array}$ \\
\hline Glucose & $120 \mathrm{mg} \mathrm{dl}^{-1}$ & 3 & 3.02 & 0.66 \\
\hline Cellulose & $120 \mathrm{mg} \mathrm{dl}^{-1}$ & 3 & 3.02 & 0.66 \\
\hline Glycine & $50 \mu \mathrm{M}$ & 3 & 3.04 & 1.3 \\
\hline Aspartic acid & $50 \mu \mathrm{M}$ & 3 & 3.01 & 0.33 \\
\hline Lysine & $50 \mu \mathrm{M}$ & 3 & 3.04 & 1.3 \\
\hline Methionine & $50 \mu \mathrm{M}$ & 3 & 3.01 & 0.33 \\
\hline Albumin & $50 \mathrm{mg} / \mathrm{ml}$ & 3 & 3.02 & 0.66 \\
\hline Ascorbic acid & $50 \mu \mathrm{M}$ & 3 & 3.07 & 2.3 \\
\hline Uric Acid & $50 \mu \mathrm{M}$ & 3 & 3.05 & 1.6 \\
\hline Triton $\mathrm{x} 100$ & $0.5 \% \mathrm{v} / \mathrm{v}$ & 3 & 2.9 & 3.3 \\
\hline EDTA & $20.0 \mu \mathrm{M}$ & 3 & 3 & 0.0 \\
\hline Heparin & $78.4 \mathrm{USP} / 10 \mathrm{~mL}$ & 3 & 3 & 0.0 \\
\hline
\end{tabular}


The reliability of the disubstituted quinone method was also examined, using homogenized red blood cells as a source of catalase activity. The disubstituted quinone method was used to evaluate catalase enzyme activity, and the results were compared with those using the peroxovanadate protocol, as described by Hadwan and Ali [10]. Similar buffers, samples, and reagents were utilized during both methods. Table 4 demonstrates that the disubstituted quinone assay has good precision. In addition, the data obtained from the disubstituted quinone method were significantly associated with the data obtained from the peroxovanadate assay, as shown in Table 5.

Table 4. Precision of the disubstituted quinone method.

\begin{tabular}{|l|l|l|l|l|}
\hline & n. & $\begin{array}{l}\text { Mean }( \pm \text { SD): } \\
\text { U.mL }\end{array}$ & $\begin{array}{l}\text { 95\% Confidence } \\
\text { Interval }\end{array}$ & CV\% \\
\hline Within-run & 20 & $7.5 \pm 0.2$ & $(7.41$ to 7.59$)$ & $2.6 \%$ \\
\hline Between-run & 20 & $7.38 \pm 0.35$ & $(7.15$ to 7.45$)$ & $4.7 \%$ \\
\hline
\end{tabular}

Table 5. The statistical correlation between the catalase activity assessments obtained from the disubstituted quinone method and those from the peroxovanadate method.

\begin{tabular}{|l|c|}
\hline The numbers of measurements & 20 \\
\hline $\begin{array}{l}\text { Mean of catalase activity that assessed by the present method } \\
\text { U.mL }\end{array}$ & 5.74 \\
\hline $\begin{array}{l}\text { Mean of catalase activity that assessed by the peroxovanadate } \\
\text { method U.mL }\end{array}$ & 5.67 \\
\hline Mean of catalase activity that assessed by both methods U.mL ${ }^{-1} \cdot$ & 5.7 \\
\hline The regression coefficient B & 0.9863 \\
\hline The regression coefficient A & -0.101 \\
\hline The correlation coefficient & 1.006 \\
\hline
\end{tabular}

The recovery of added known catalase enzyme activities (HiMedia company; the code product: TC037, India) was used to determine the accuracy of the current method. In these experiments, catalase enzyme solution was prepared in cold phosphate buffer $(\mathrm{pH}$ 7; $50 \mathrm{mM}$ ), and the resulting activity was standardized using the peroxovanadate method. The recovery of catalase enzyme activity was equal to $92 \%$ in the presence of $10 \mathrm{U} \cdot \mathrm{mL}^{-1}$ of enzyme and increased to $97.15 \%$ when the activity of the enzyme was varied between 0.5 to $6.5 \mathrm{U} \cdot \mathrm{mL}^{-1}$ (Table 6). 
Table 6. Recovery of catalase enzyme activity after the addition of catalase to enzymatic reaction solutions.

\begin{tabular}{|c|c|c|c|c|}
\hline $\begin{array}{c}\text { Contents of catalase } \\
\text { enzyme }\end{array}$ & $\begin{array}{c}\text { Catalase } \\
\text { enzyme } \\
\text { activity } \\
\text { added } \\
\text { U.mL }^{-1}\end{array}$ & $\begin{array}{c}\text { Catalase } \\
\text { enzyme } \\
\text { calculated } \\
\text { activity } \\
\text { U.mL }^{-1}\end{array}$ & $\begin{array}{l}\text { Catalase } \\
\text { enzyme } \\
\text { observed } \\
\text { activity }^{\text {a }} \\
\text { U.mL }^{-1}\end{array}$ & $\begin{array}{c}\text { Recovery } \\
\%\end{array}$ \\
\hline Enzymatic sample & ----- & ----- & 3.0 & ----- \\
\hline $\begin{array}{l}\text { Catalase enzyme added }+ \\
\text { enzymatic sample }\end{array}$ & 0.5 & 3.5 & 3.6 & 97.15 \\
\hline $\begin{array}{c}\text { Catalase enzyme added + } \\
\text { enzymatic sample }\end{array}$ & 1.0 & 4.0 & 4.1 & 97.5 \\
\hline $\begin{array}{c}\text { Catalase enzyme added + } \\
\text { enzymatic sample }\end{array}$ & 2.0 & 5.0 & 4.9 & 98 \\
\hline $\begin{array}{c}\text { Catalase enzyme added }+ \\
\text { enzymatic sample }\end{array}$ & 3.0 & 6.0 & 6.1 & 98.88 \\
\hline $\begin{array}{c}\text { Catalase enzyme added + } \\
\text { enzymatic sample }\end{array}$ & 4.0 & 7.0 & 7.05 & 99.3 \\
\hline $\begin{array}{c}\text { Catalase enzyme added + } \\
\text { enzymatic sample }\end{array}$ & 5.0 & 8.0 & 7.85 & 98.13 \\
\hline $\begin{array}{c}\text { Catalase enzyme added }+ \\
\text { enzymatic sample }\end{array}$ & 6.0 & 9.0 & 8.9 & 98.99 \\
\hline $\begin{array}{c}\text { Catalase enzyme added + } \\
\text { enzymatic sample }\end{array}$ & 6.5 & 9.5 & 9.1 & 95.8 \\
\hline $\begin{array}{c}\text { Catalase enzyme added }+ \\
\text { enzymatic sample }\end{array}$ & 7.0 & 10 & 9.2 & 92 \\
\hline
\end{tabular}

Various dilutions of red blood cell homogenates were used to evaluate the sensitivity of the disubstituted quinone method. The sensitivity was determined by comparing the measured catalase activity against the expected catalase activity, as shown in Fig. 2. The present activity was adjusted using the peroxovanadate method, whereas the expected activity was measured using the disubstituted quinone method. The correlation between the measured catalase activity and the expected catalase activity was highly linear $(r=0.9982)$, and the best linear curve passed through the origin. 


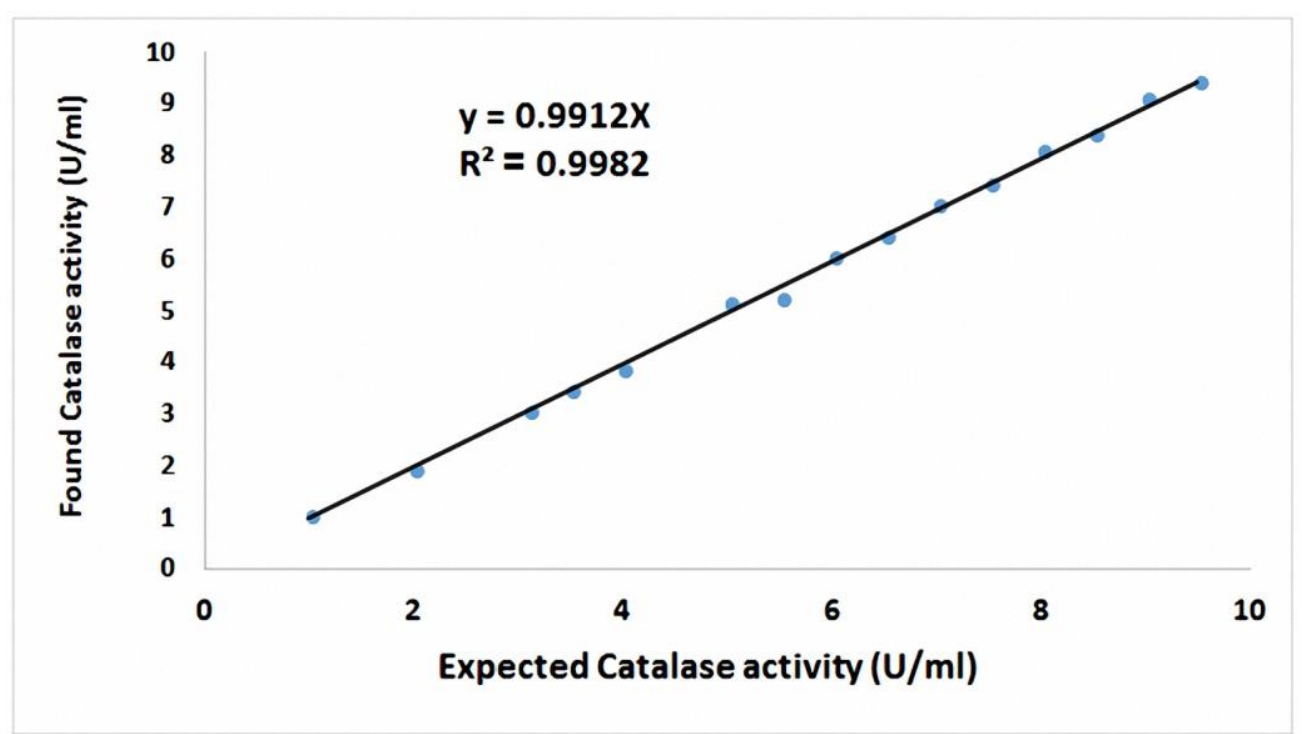

Figure 2. Comparison between the catalase enzyme activities of RBC homogenates obtained by utilizing the disubstituted quinone method and peroxovanadate method.

Catalase activity assays were then performed using lysates from five different bacterial laboratory strains to clarify the further potential applications of the disubstituted quinone method. The results of these experiments indicated that similar catalase enzyme activities were obtained using the disubstituted quinone method as were obtained using the peroxovanadate method in bacterial strains, as described by Hadwan and Ali [10]. In agreement with their findings, our results (Table 7) showed that Staphylococcus aureus has higher catalase enzyme activity than other types of bacteria.

Table 7. Comparison between the disubstituted quinone and peroxovanadate methods for the assessment of catalase activities (KU) in different types of bacteria.

\begin{tabular}{|l|l|l|}
\hline Name of bacteria & $\begin{array}{l}\text { Peroxovanadate } \\
\text { method }\end{array}$ & $\begin{array}{l}\text { Disubstituted quinone } \\
\text { method }\end{array}$ \\
\hline Staphylococcus aureus & 15.5 & 15.2 \\
\hline pseudomonas aeruginosa & 12.0 & 12.3 \\
\hline Escherichia coli & 7.7 & 7.5 \\
\hline Klebsiella pneumonia & 12.0 & 12.7 \\
\hline Enterococcus faecalis & 0 & 0 \\
\hline
\end{tabular}

The disubstituted quinone method was utilized to assess catalase enzyme activities in liver tissue homogenates from male albino mice, male albino rats, and broiler chickens. Liver tissue homogenates exhibited high catalase enzyme activities (Fig. 3). 


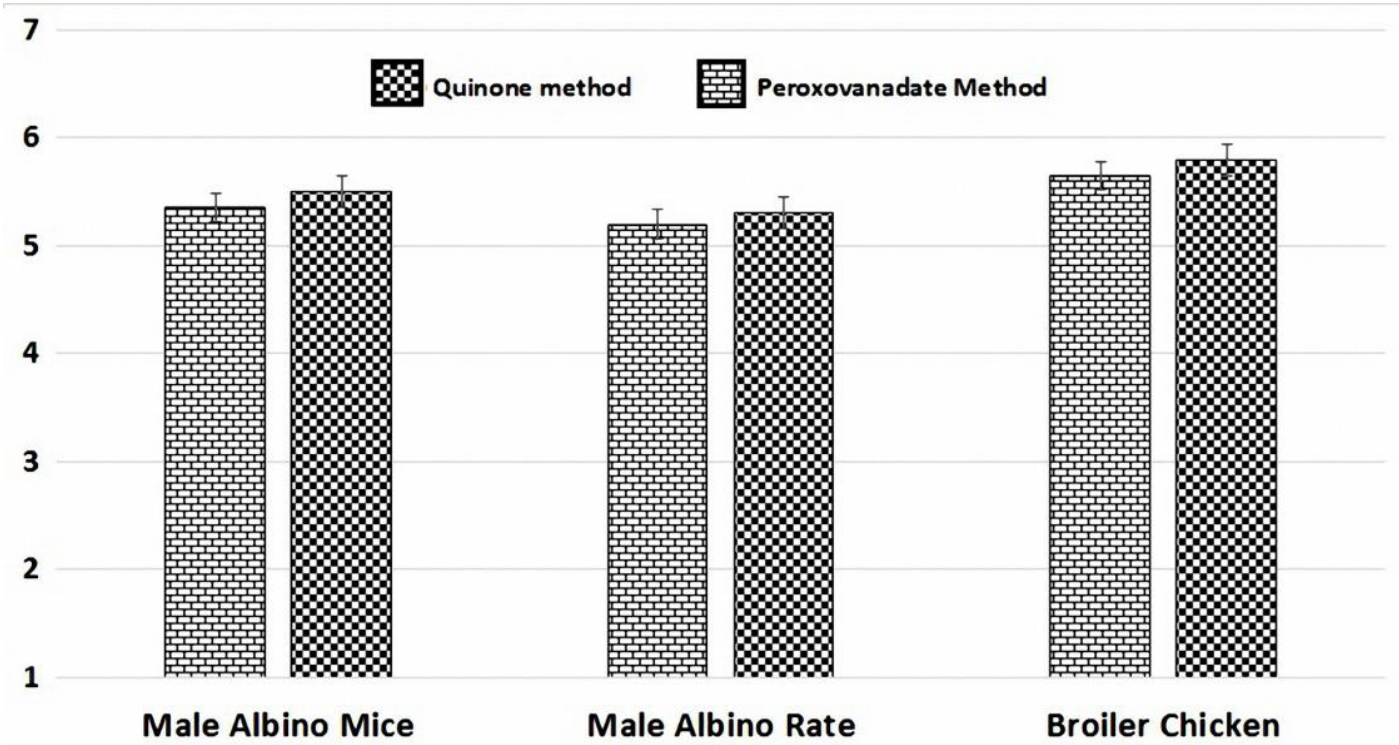

Figure 3. Comparison between the disubstituted quinone and peroxovanadate methods for the measurement of catalase activities in tissue homogenates.

The assessment of catalase activity represents a good method for determining the ability of the liver to resist oxidative stress [25], and many scientific reports have investigated catalase enzyme activities in the livers of albino rats and mice [26, 27].

In parallel, the evaluation of oxidative stress in broiler chickens has been used to assess catalase activities in the liver [28, 29]. Moreover, Khanian et al. [30] utilized catalase activity measurements from the livers of broiler chickens to study the effects of Lactobacillus plantarum 299v consumption on growth and aflatoxin-related oxidative damage in the liver. In addition, Hassan et al., [31] were utilized catalase measurements of broiler chicken livers to clarify the effects of rutin on growth performance, antioxidant capacity, lipid-related transcript expression, and the economics of broiler chickens.

The disubstituted quinone assay presents several improvements over other protocols used to assess catalase enzyme activities in biological tissues. First, this method is free from the negative characteristics associated with the UV spectrophotometric method. The disubstituted quinone method requires a hydrogen peroxide concentration equal to $10 \mathrm{mM}$, in contrast with the UV spectrophotometric method, which requires a hydrogen peroxide concentration equal to $30 \mathrm{mM}$, which is a 
high enough concentration to inhibit catalase by modifying its active site structure [32]. Additionally, proteins and DNA molecules can absorb UV light during the UV spectrophotometric method, whereas the disubstituted quinone assay is based upon the decreased absorbance of the characteristic disubstituted quinone band at $550 \mathrm{~nm}$, which is not in the UV spectrum. The disubstituted quinone protocol could be made accessible as assay kits, does not require the use of cumbersome techniques, and is inexpensive. Additionally, the method is simple, shows high precision, and can be applied at low $\mathrm{H}_{2} \mathrm{O}_{2}$ concentrations and in the presence of significant quantities of several types of biochemicals without interference.

\section{Conclusion}

A simple and precise assay for estimating catalase enzyme activity was developed and described in this study. This is a simple and cost-effective method, with the advantages of high precision and accuracy and requiring only instruments that are readily available in most laboratories.

\section{Competing financial interests}

The author declares no competing financial interests.

\section{Competing interests}

The authors declare that they have no competing interests with the contents of this paper.

\section{Acknowledgements}

We thank our colleagues in University of Babylon/College of Science for their technical supporting, comments and help regarding our study, especially Dr. Noor S. K. AlKhafaji.

\section{References}

1. Glorieux C, Zamocky M, Sandoval JM, Verrax J, Calderon PB. Regulation of catalase expression in healthy and cancerous cells. Free Radical Biology and Medicine. 2015 Oct 1;87:84-97.

2. Rahman I, Biswas SK, Kode A. Oxidant and antioxidant balance in the airways and airway diseases. European journal of pharmacology. 2006 Mar 8;533(13):222-39.

3. Zaidi SK, Ansari SA, Tabrez S, Naseer MI, Shahwan MJ, Banu N, Al-Qahtani $\mathrm{MH}$. Antioxidant potential of Solanum nigrum aqueous leaves extract in 
modulating restraint stress-induced changes in rat's liver. Journal of pharmacy \& bioallied sciences. 2019 Jan;11(1):60.

4. Yao XH, Min H, Lü ZH, Yuan HP. Influence of acetamiprid on soil enzymatic activities and respiration. European Journal of Soil Biology. 2006 Apr $1 ; 42(2): 120-6$.

5. Aebi H. [13] Catalase in vitro. InMethods in enzymology 1984 Jan 1 (Vol. 105, pp. 121-126). Academic Press.

6. Mueller S, Riedel HD, Stremmel W. Determination of catalase activity at physiological hydrogen peroxide concentrations. Analytical biochemistry. 1997 Feb 1;245(1):55-60.

7. Ou P, Wolff SP. A discontinuous method for catalase determination at 'near physiological'concentrations of $\mathrm{H} 2 \mathrm{O} 2$ and its application to the study of $\mathrm{H} 2 \mathrm{O} 2$ fluxes within cells. Journal of biochemical and biophysical methods. 1996 Jan 11;31(1-2):59-67.

8. Hadwan MH. Simple spectrophotometric assay for measuring catalase activity in biological tissues. BMC biochemistry. 2018 Dec;19(1):7.

9. Masuoka N, Wakimoto M, Ubuka T, Nakano T. Spectrophotometric determination of hydrogen peroxide: catalase activity and rates of hydrogen peroxide removal by erythrocytes. Clinica chimica acta. 1996 Oct 29;254(2):101-12.

10. Hadwan MH, kadhum Ali S. New spectrophotometric assay for assessments of catalase activity in biological samples. Analytical biochemistry. 2018 Feb 1;542:29-33.

11. Shivakumar A, Nagaraja P, Chamaraja NA, Krishna H, Avinash K. Determination of catalase activity using chromogenic probe involving isonicotinicacidhydrazide and pyrocatechol. Journal of biotechnology. 2011 Oct 10;155(4):406-11.

12. Posch HE, Wolfbeis OS. Optical sensor for hydrogen peroxide. Microchimica Acta. 1989 Jan 1;97(1-2):41-50.

13. Cohen CB, Weber SG. Photoelectrochemical sensor for catalase activity based on the in situ generation and detection of substrate. Analytical Chemistry. 1993 Jan 1;65(2):169-75.

14. Bekdeşer B, Özyürek M, Güçlü K, Alkan FÜ, Apak R. Development of a new catalase activity assay for biological samples using optical CUPRAC sensor. Spectrochimica Acta Part A: Molecular and Biomolecular Spectroscopy. 2014 Nov 11;132:485-90.

15. Siqueira AJ, Remião JO, Azevedo AM, Azambuja CR. A gasometric method to determine erythrocyte catalase activity. Brazilian journal of medical and biological research. 1999 Sep;32(9):1089-94.

16. Kroll RG, FREARS ER, BAYLISS A. An oxygen electrode-based assay of catalase activity as a rapid method for estimating the bacterial content of foods. Journal of Applied Bacteriology. 1989 Mar;66(3):209-17.

17. Slaughter MR, O’Brien PJ. Fully-automated spectrophotometric method for measurement of antioxidant activity of catalase. Clinical biochemistry. 2000 Oct 1;33(7):525-34. 
18. Abderrahim M, Arribas SM, Condezo-Hoyos L. A novel pyrogallol red-based assay to assess catalase activity: Optimization by response surface methodology. Talanta. 2017 May 1;166:349-56.

19. Huang XM, Zhu M, Shen HX. N, N-diethylaniline as hydrogen donor for determination of hydrogen peroxide catalyzed by metalloporphyrins as enzyme mimetic of peroxidase. Microchimica Acta. 1998 Mar 1;128(1-2):87-91.

20. Ci YX, Wang F. Spectrofluorimetric determination of hydrogen peroxide based on the catalytic effect of peroxidase-like manganese tetrakis (sulphophenyl) porphyrin on the oxidation of homovanillic acid. Analytica Chimica Acta. 1990 Jan 1;233:299-302.

21. Elnemma EM. Spectrophotometric determination of hydrogen peroxide by a hydroquinone-aniline system catalyzed by molybdate. Bulletin of the Korean Chemical Society. 2004;25(1):127-9.

22. Nardello V, Bouttemy S, Aubry JM. Olefin oxidation by the system $\mathrm{H} 2 \mathrm{O} 2 \mathrm{MoO} 2-4$ : competition between epoxidation and peroxidation. Journal of Molecular Catalysis A: Chemical. 1997 Mar 14;117(1-3):439-47.

23. Wahlen J, De Vos DE, Groothaert MH, Nardello V, Aubry JM, Alsters PL, Jacobs PA. Synergism between molybdenum and lanthanum in the disproportionation of hydrogen peroxide into singlet oxygen. Journal of the American Chemical Society. 2005 Dec 14;127(49):17166-7.

24. Hadwan MH, Abed HN. Data supporting the spectrophotometric method for the estimation of catalase activity. Data in brief. 2016 Mar 1;6:194-9.

25. Shin SK, Cho HW, Song SE, Bae JH, Im SS, Hwang I, Ha H, Song DK. Ablation of catalase promotes non-alcoholic fatty liver via oxidative stress and mitochondrial dysfunction in diet-induced obese mice. Pflügers ArchivEuropean Journal of Physiology. 2019 Jun 1;471(6):829-43.

26. Adisa RA, Kolawole N, Sulaimon LA, Brai B, Ijaola A. Alterations of Antioxidant Status and Mitochondrial Succinate Dehydrogenase Activity in the Liver of Wistar Strain Albino Rats Treated with by Ethanol Extracts of Annona senegalensis Pers (Annonaceae) Stem Bark. Toxicological research. 2019 Jan;35(1):13.

27. Aldulaimi AM, Husain FF. Effect of Aqueous Extract Cyperus rotundus Tubers as Antioxidant on Liver and Kidney Functions in Albino Males Rats Exposed to Cadmium Chloride Toxic. Baghdad Science Journal. 2019;16(2):315-22.

28. Qadri SS, Biswas A, Mir NA, Mandal AB, Biswas AK. Physico-biochemical and microbial characteristics of broiler chicken meat fed diet incorporated with Kappaphycus alvarezii. Journal of Applied Phycology. 2019:1-7. 
29. Baradaran A, Samadi F, Ramezanpour SS, Yousefdoust S. Hepatoprotective effects of silymarin on CCl4-induced hepatic damage in broiler chickens model. Toxicology reports. 2019 Jan 1;6:788-94.

30. Khanian M, Karimi-Torshizi MA, Allameh A. Alleviation of aflatoxin-related oxidative damage to liver and improvement of growth performance in broiler chickens consumed Lactobacillus plantarum 299v for entire growth period. Toxicon. 2019 Feb 1;158:57-62.

31. Hassan F, Roushdy E, Kishawy A, Zaglool A, Tukur H, Saadeldin I. Growth Performance, Antioxidant Capacity, Lipid-Related Transcript Expression and the Economics of Broiler Chickens Fed Different Levels of Rutin. Animals. 2019 Jan;9(1):7.

32. Mueller S, Riedel HD, Stremmel W. Determination of catalase activity at physiological hydrogen peroxide concentrations. Analytical biochemistry. 1997 Feb 1;245(1):55-60. 